\title{
A Growing Population, Rangelands \& The Future
}

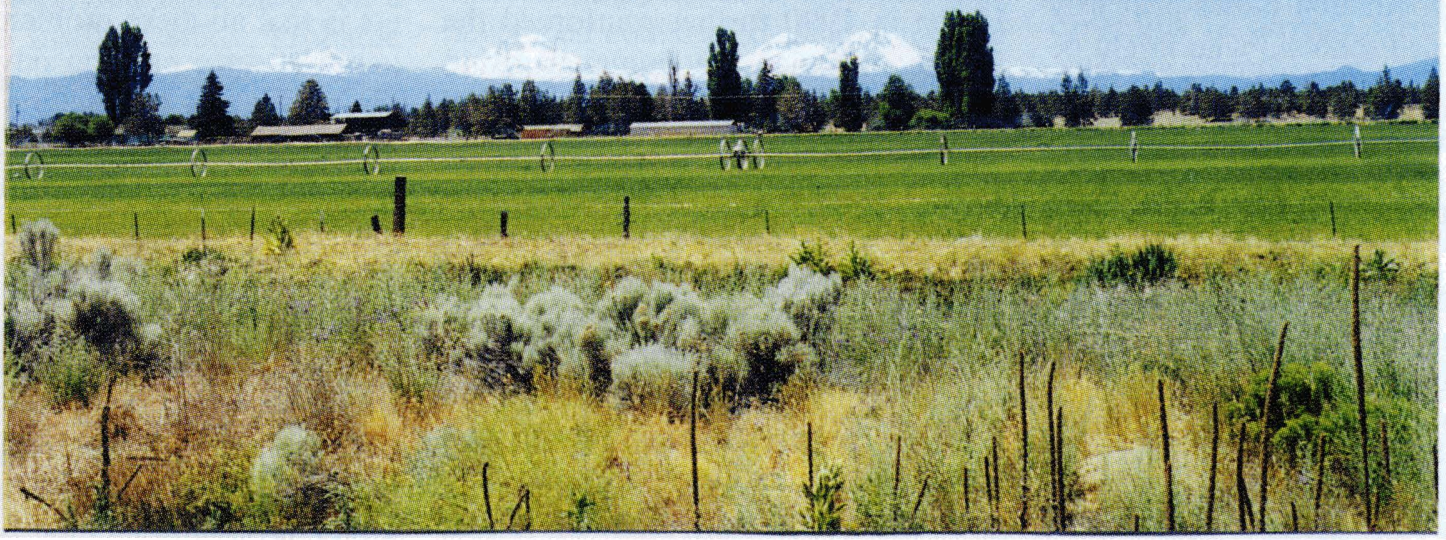

\section{The world's growing population will put added pressure on range- lands and the value of the services these lands provide.}

\author{
By Jerry Holechek
}

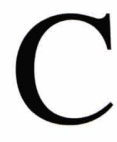

onversion of rangeland to other uses during the last 20 years has become an important management concern. This trend is largely driven by rapid human population increase and a demographic shift from the eastern to western United States. The consequences could be devastating for rangelands until they are valued for the ecosystem services they provide. Let's look to the future.

In 2000 the world's human population reached 6.1 billion which is twice as many as in 1960. Presently the world human population is growing at a rate of 80 million/year. Although fertility rates have declined faster than expected, the world population growth rate is $1.3 \%$ /year compared to $1.5 \%$ in 1990. By 2050 it is expected that 10 billion people will inhabit the planet (Table 1).

Over the past 300 years, world population growth rates per year increased from $0.3 \%$ in 1700 to $0.6 \%$ in 1900 to the current rate of $1.3 \%$. This rate of increase has actually exceeded the growth rate calculated by Thomas Malthus (1768-1834) who predicted the world human population would exceed food supplies sometime between 1850-1900 (Kleiber 1961). Although birth rates have fallen substantially from six children in 1900 to 2.2 children per female in 2000 , human longevity has increased from 40 years (1900) to 60-80 years (2000) depending on country.

Improved healthcare, rapid increases in food production, and other technological advances explain how the world today can support nearly four times more people than in 1900 at a much higher standard of living. Although various scenarios are possible, most experts believe the world's

Table 1. Projection of world population in millions of people and its geographical distribution.

\begin{tabular}{|c|c|c|c|c|c|}
\hline \multicolumn{6}{|c|}{ Year } \\
\hline Area & 1950 & 1995 & 2050 & 2100 & 2150 \\
\hline World & 2524 & 5687 & 9367 & 10414 & 10806 \\
\hline Africa & 224 & 719 & 2046 & 2646 & 2770 \\
\hline Asia & 1402 & 3438 & 5443 & 5851 & 6059 \\
\hline China & 555 & 1220 & 1517 & 1535 & 1596 \\
\hline India & 358 & 929 & 1533 & 1617 & 1669 \\
\hline Europe & 547 & 728 & 638 & 579 & 595 \\
\hline North America & 172 & 297 & 384 & 401 & 414 \\
\hline $\begin{array}{l}\text { Latin America and } \\
\text { the Caribbean }\end{array}$ & 166 & 477 & 810 & 889 & 916 \\
\hline Oceania & 13 & 28 & 46 & 49 & 51 \\
\hline
\end{tabular}

Sources: Mc Queen 2000; United Nations 1998. 
human population will be between 10 and 12 billion by 2100 . This will lead to unprecedented demands on the earth's natural resources.

\section{A Doomsday \& Cornucopia View}

During my career in natural resource management, I have been influenced on human population issues primarily by two learned scholars who might be referred to as Dr. Doomsday (Paul Erlich) and Dr. Cornucopia (Julian Simon).

In the late 1960's when I attended college, Dr. Erlich had recently completed his book titled "The Population Bomb." This book made a convincing doomsday case that human population growth would overwhelm food production capability and cause severe pollution in the last 30 years (19702000) of the twentieth century. This supposedly would cause widespread human misery from famine, disease, and war leading ultimately to a major reduction in both human population and quality of environmental support systems (land, air, water, energy, genetic material).

A contrasting cornucopian view espoused by Dr. Simon in his 1981 book "The Ultimate Resource" became popular under the Reagan administration. The essence of this view was that environmental problems were greatly exaggerated and people (brainpower) are the most vital resource in solving the world's problems. In order to unleash this brainpower, democratic, market oriented social political systems are required. Basically the idea here is that technology involving substitution, miniaturization, recycling, molecular engineering, and other innovations can overcome any kind of scarcity or environmental problem brought about by more people.

Generally the doomdayers have had their training in biological or ecological sciences while the cornucopians have an economic or financial background. The 1970's gave credibility to the doomsdayers as food and energy prices rose sharply, famines occurred in China and India, and the United States experienced both economic stagnation and high inflation. However, President Ronald Reagan implemented a set of supply side economic policies in the 1980's that helped revive economic growth and stabilized food and energy prices. The fall of Communism in the Soviet Union in 1990 further reinforced the cornucopian view that human hardship was primarily a function of unsound social/political policies.

It is generally accepted by ecologists and biologists that at some point physical resources will determine the limit of human population growth. Estimates of world human carrying capacity fall between 4 to 16 billion people. These estimates do not take into account quality of life, and they assume equity in distribution of resources.

Presently $18 \%$ of the world's population (1.1 billion people) live in severe poverty and life is hardly comfortable. The richest seven nations (USA, Canada, Great Britain, France, Germany, Japan, Italy) have only $10 \%$ of the world's population but annually account for $40 \%$ of the consumption of fossil fuels, forest products, and a variety of other commodities. The world's consumption rate of natural resources has grown even faster than the human population since 1950 . However, climatic change and creation of pollution in excess of the world's detoxification capabilities are of more immediate concern than resource exhaustion.

The major constraints that confront mankind worldwide over the next 50 years include food scarcity, water scarcity, water contamination, climatic change, air contamination, energy scarcity, farmland depletion and loss of bio-diversity.

Destruction of rain forest is a particular concern because of the critical value of these areas in preventing climatic change and extinction of plant and animal species. About $35 \%$ of the world's forests have been removed since 1900. Extinctions of plant and animal species are now occurring at 50 to 100 times faster than their natural rate. Unsound farming practices and overgrazing have degraded $16 \%$ of the world's land area. World fisheries are a particular problem with $25 \%$ now depleted and another $44 \%$ being over harvested.

The primary fear of the doomsdayers is that all these problems will converge at once causing devastation of the planet and elimination of $75 \%$ or more of the human population. Let's examine the primary components of this issue:

\section{Water}

Water will likely be the biggest constraint on world population growth in the near term. It is already a major problem in the western United States. Water problems include depletion of underground aquifers, contamination of ground water, siltation of dams, salinization of irrigation water, prolonged drought, and flooding. By $202540 \%$ of the world's population will likely experience water shortages (United Nations Development Programme 2000). Global availability of water has dropped from 4.5 million gallons per person in 1950 to 1.8 million gallons in 1998. Currently 20 countries are experiencing water stress (less than 264,200 gallons per person).

Irrigation has contributed greatly to increases in world food production since 1950 . The amount of irrigated land in the world nearly tripled between 1950 and 2000. However, future increases from irrigation will be much more limited. Various reports show the world's ground water is being rapidly depleted. In the United States, this problem is most severe in the states of Texas, New Mexico, Arizona, and California. However this problem to some extent can be overcome by appropriating water from agriculture. That's exactly what the City of El Paso has done. They have purchased ranches with underground aquifers near Van Horn, Dell City and 
other locations. Farmers and ranchers in these areas are rightfully worried that El Paso will suck their lands dry, effectively ending agriculture.

\section{Energy}

Proven world reserves of oil, gas, and coal are officially estimated to be 43,61 , and 228 years respectively at current consumption rates based on a recent Cato Institute study. Probable reserves (includes those undiscovered) of oil, gas, and coal are officially forecast to be 114,200 , and 1,884 years of present usage.

Unconventional fossil fuel sources such as oil tars and shale oil might extend the day of reckoning decades or centuries into the future if new extraction and refinement technologies can be developed. On the negative side, extraction is becoming a bigger problem with proven oil reserves. Between 1987 and 1999 total world energy use increased $17 \%$. Some experts believe that rising world demand coupled with depletion of readily extractable oil reserves will cause world scarcity by 2018. Keep in mind the proven oil reserves are expected to last 43 years at current consumption rates, but world oil demand is rapidly rising due to global economic expansion.

The USA now imports about 55\% of its oil due to diminishing reserves. More fuel-efficient cars and alternative power for cars (fuel cell, electric power) might reduce per capita fossil fuel consumption by $25 \%$ to $50 \%$ within 25 years. On the other hand there could be $25 \%$ more people in the USA, and $50 \%$ more in the world. There is concern greater use of energy per capita could occur particularly in developed countries where new electronic technologies regarding the Internet and household appliances are being rapidly applied. Gasoline efficiency by automobiles in the USA has actually decreased from 26 to 24 miles per gallon in the last 5 years due to increased use of sport utility vehicles.

\section{Food}

Improvements in agriculture have increased world per capita food production by roughly $25 \%$ since the mid 1970's. Real food prices in most countries have fallen $10-30 \%$ over the past 20 years. This contradicts 1970 doomsday projections that food prices would rise $100 \%$ by year 2000 . Unfortunately modern agriculture in developed countries depends on using increasing amounts of fossil fuels for cultivation, harvesting, fertilizer production, irrigation, processing and distribution.

World grain yield increases are now slowing down. The average annual increase in world grain yield per acre was $2.1 \%$ for the 1950 to 1990 period compared to $1.2 \%$ for the 1990 to 2000 period.

Another major food production concern is the trend towards globalization, specialization, and urbanization. This is reducing food self sufficiency in both developed and developing countries. Often the most productive farmlands are urbanized in developed countries. This not only shrinks the agricultural land base but necessitates massive food transportation and delivery systems to keep the expanding urban center supplied. If water, farmland, and energy resources shrink and the large urban centers continue to expand there is concern that the USA will lose its capability to be a large grain exporter. Presently the USA plays a key role in providing developing countries with grain and preventing worldwide scarcity when climatic conditions are unfavorable.

Currently about $17 \%$ of the world's human population suffers from some degree of undernourishment. Most of these people are in Africa and Asia where human population growth is greatest. Shrinkage in water, land and energy supplies per individual is raising deep concerns about the capability of subsistence agriculture to meet food needs in these regions. The problem with conversion to industrialized agriculture is that it causes massive dislocation of rural populations to urban areas and is fossil fuel dependent.

Governments in developing countries do not have the financial means to purchase and distribute large amounts of imported foods. Most of these underdeveloped countries currently have high debt levels. It is questionable that food-exporting countries like the USA over the next 15 years will have the physical and financial capability to provide free food to developing countries on a massive scale. Future unrest over food in Asia and Africa has the potential for serious internal political turmoil and world war as more countries obtain nuclear and biological weapons.

In the USA five factors that undermine food security are loss of farmland to urbanization, depletion of aquifers, loss of irrigation water to urbanization, heavy reliance on fossil fuels, and soil erosion. According to the USDA-Natural Resources Conservation Service, there are 382 million acres of farmland in the USA. Since 1980 the USA has been losing a half million acres a year to urbanization. Appropriation of irrigation water for urban uses and aquifer depletion could shrink the farmland base by 10 to 15 million acres within 20 years. The Oglalla aquifer in the southern Great Plains is the region where most of this loss will occur.

Perhaps a bigger problem is incapability of USA farmland soils to produce bumper crops without massive inputs of fertilizer, herbicides, and pesticides. Some experts believe a forced return to low input (reduced use of fossil fuels) farming techniques would reduce yields by as much as $50 \%$. A major concern is that soil erosion and continuous use of the same crops year after year have severely depleted soil nutrient and water holding capabilities. Increasingly higher inputs of fertilizer, irrigation, herbicides, and pesticides are required to obtain equivalent yields.

\section{Climatic Change}

Carbon dioxide is an unavoidable product of burning fossil fuels. It ab- 
sorbs heat radiated from the earth's surface in a process known as the greenhouse effect. Various government reports now show that human activities involving release of carbon dioxide cause global warming.

Some of the evidence of global warming is that 14 of the hottest years on record have occurred since 1980 , the retreat of glaciers, rising sea levels, and increasing intensity of thunderstorms and hurricanes. Expected changes from global warming include rising oceans that will inundate coastal cities displacing large human populations, a shifting of the rich farmlands of the central USA northward to Canada, massive mortality of forests that lack time to adapt and accentuation of hydrologic cycles causing great seasonal extremes of temperature and water runoff. This last impact is the one of most immediate concern.

Some climatologists believe that increasingly sharp climatic fluctuations caused by global warming will make crop production much more risky and difficult. This would greatly elevate energy costs needed for home heating and cooling. Intense droughts followed by intense flooding may increasingly occur. By 2025 some climatologists predict the world's climate could be so erratic that world food production could be reduced by one half or more.

\section{Endangered Species}

World endangered species problems can only increase in the $21^{\text {st }}$ century as land use intensifies and habitats become more fragmented. It will be particularly difficult to maintain many of the large African herbivores and predators. In the USA the Endangered Species Act of 1973 will likely collide with pressures for economic development. Rising land, water, food, wood, and energy prices in the USA could force changes in approaches to endangered species classification and protection. Hopefully these changes will reward landowners for protection of endangered species habitat and be rational in endangered species classification and recovery prescriptions.

Table 2. Examples of rangeland ecosystem services and goods.

\section{Services}

Maintenance of Atmospheric Quality

Control and Amelioration of Climate

Regulation of Freshwater Supplies

Origin and Maintenance of Soils (and their buffering capacity)

Detoxification and Degradation of Wastes (Pollution dilution)

Natural Control of Pathogenic and Parasitic Organisms (Pest control)

Pollination of Cultivated and Wild Plants

Purification of Air and Water

Renewal of Soil and Water Fertility

Retention and Delivery of Nutrients to Plants by Soils and Water

Genetic Resources (Improve existing and developing new domestic plants and animals)

Aesthetic, Cultural, Spiritual Renewal

Recreational Services

\section{Goods}

Foods (mammals, birds, fish, shellfish and other invertebrates, plants, fruits, nuts, spices)

Fibers (cotton, flax, hemp, wool, leather, cashmere, silk)

Fuels (botanochemicals)

Pharmaceuticals and Medicines (psychoactive drugs, codeine, diuretics, pain killers, antibiotics)

Building Materials (lumber and other woody materials, resins, glues, shellac)

Industrial Products (waxes, rubber, dyes, vegetable fats and oils)

Cooking Oils (plant and animal fats and oils)

Sources: Daily (1997) and West (1995).

\section{How Will Rangelands Be Affected?}

Rangeland involves about $70 \%$ of the world's land area and $50 \%$ of the USA's land area. They play a critical role in providing humankind with various goods and services needed for survival (Table 2). Unfortunately many of these services are taken for granted by the public. Tax systems in the USA and worldwide are actually somewhat punitive in regard to services provided on privately owned rangelands.

To adequately accommodate future population growth and avoid environmental catastrophe in the USA, the USA will probably have to make major changes in how it deals with this issue. Over the next 100 years as much as $40 \%$ of the USA's rangeland could be lost to other uses (Table 3). Private rangelands are valued primarily for their income from livestock and in some cases wildlife. In New Mexico this equates to $\$ 30$ to $\$ 60$ per acre for grazing but $\$ 300$ to $\$ 2000$ per acre in many areas if subdivided for ranchettes, housing, or other uses. Most small and medium sized ranches in New Mexico have been losing money since 1994. In Utah a recent survey showed one third of the ranchers on private land eventually plan to subdivide (Peterson and Coppock 2001). The small family ranch in Central Oregon shown in Figure 1 is an example of the dilemma.

In order to save these types of operations, changes in government policies will be needed that create greater incentives for conservation easements, lower property tax rates and provide payments to ranchers for provision of ecosystem services. Already this approach is being applied to farmlands through the USDA-Conservation Reserve Program and associated programs that pay farmers to provide buffer strips around fields and riparian areas, to preserve wetlands, and to establish trees for windbreaks.

On rangelands a similar approach has been proposed by Ward (1999). Under this approach, ranchers would receive government payments for application of light stocking rates that maintain high levels of ground cover, upgrading of riparian zones with trees and shrubs, development of ponds that enhance wildlife habitat, and brush/weed control practices that increase ecosystem services as well as livestock forage. Financial incentives for maintaining high levels of residual vegetation would help the Environmental Protection Agency with its goal of reducing carbon dioxide levels in the at- 
Table 3. Some uses of rangeland that increasingly reduce the amount of open space and amount available for livestock production.

\begin{aligned} & \hline \hline 1. Ranchettes \\ & 2. Airports \\ & 3. Prisons \\ & 4. Bombing ranges \\ & 5. Waste disposal sites \\ & 6. Wind farms \\ & 7. Solar energy farms \\ & 8. Jetports \\ & 9. Parks \\ & 10. Industrial sites \\ & 11. Dams \\ & 12. Golf courses \\ & 13. Parking lots \\ & 14. Museums \\ & 15. Shooting ranges \\ & 16. High density homes \\ & 17. Government buildings \\ & 18. Powerlines \\ & 19. Railroads \\ & 20. Oil and gas lines \\ & 21. Highways and roads \\ & 22. Oil refineries \\ & 23. Sewage processing \\ & 24. Fairgrounds \\ & 25. Motor courses \\ & 26. Power plants \\ & 27. Shopping centers \\ & 28. College campuses \\ & 29. Junkyards \\ & 30. Agricultural processing plants \\ & \hline\end{aligned}

mosphere. Improving carbon sequestration capabilities of degraded lands depends on increasing both living and nonliving vegetation (i.e. above and below ground biomass).

\section{Re-Thinking Consumer Uses}

Federal, state, and local governments may have to re-think several macro-economic policies that affect land use, water consumption, and energy consumption. Changing the tax system so greater emphasis is placed on resource consumption and less on income generation has been advocated by many natural resource economists.

Under this approach taxes on gasoline, second homes, second cars, excessive water use, and other luxuries would be greatly increased while there would be little or no income tax. People that live close to their work and used mass transportation systems would receive tax breaks over those commuting long distances in privately owned vehicles. Heavy taxes would be levied on fuel inefficient vehicles (sport utility vehicles). Property taxes would be more in accordance with infrastructure requirements for nonfarm/ranch dwellings outside of incorporated towns and cities.

Although draconian, these changes will likely be needed if projected increases in human population occur and no major breakthroughs occur that rapidly solve impending energy, water, food, wood, and pollution problems.

The USA has just been through a 20 year era of relatively cheap land, water, food, wood, and energy that has lead to life style extravagances that will probably be moderated. Within the last two years energy, water, and land costs have started to increase in the USA. Food costs are likely to follow. Fertilizer costs alone have doubled in 2001 compared to 1999 . This trend will undoubtedly affect how people use natural resources, and their choices on human population issues.

Stabilization of human population growth and conserving natural resources to the extent possible is a rational hedge against climatic adversity and the possibility that technology will not always stay ahead of human population growth. Rangelands, because they occupy large areas and are relatively undeveloped, play a critical role in provision of ecosystem products and services in nearly all parts of the world. Vital services from rangelands such as aquifer recharge and breakdown, and dilution of various human wastes are severely undervalued in the USA and other countries.

New economic valuation systems and policies are needed that encourage conservation of rangelands based on their capability to provide essential ecosystem services. This will be one of the great challenges facing rangeland managers in the $21^{\text {st }}$ century.

Author is professor of Range Science, Department of Animal and Range Sciences, New Mexico State University, Las Cruces. This paper was supported by the New Mexico Agricultural Experiment Station and was part of project 1-5-27417.

\section{References}

Abramovitz, J.N. 1997. Valuing natures services. State of World Report 1997. W.W. Norton \& Company, New York, N.Y.

Bright, C. 1997. Tracking the ecology of climate change. State of World Report 1997. W.W. Norton \& Company, New York, N.Y.

Brown, L. 1997. Facing the prospect of food scarcity. State of World Report 1997. W.W. Norton \& Company, New York, N.Y.

Daily, D.C. (Ed.). 1997. Natures services: societal dependence on natural ecosystems. Island Press, Washington, D.C.

Erlich, P.R. 1968. The Population Bomb. Ballantine Books, New York, N.Y.

Holechek, J.L., R. Cole, J. Fisher, and R. Valdez. 2000. Natural Resources: ecology, economics, and policy. Prentice-Hall, Upper Saddle River, N.J.

Holechek, J.L., R.W. Pieper, and C. W. Herbel. 2001. Range Management Principles and Practices. 4th Ed. Prentice-Hall, Upper Saddle River, N.J.

Kleiber, M. 1961. The fire of life. John Wiley and sons, New York, N.Y.

McQueen, R.E. 2000. World population growth, distribution and demographics and their implications on food production. Canad. J. Anim. Sci. 80:229-234.

Peterson, R. and D. L. Coppock. 2001. Economics and demographics constrain investment in Utah private grazing lands. J. Range Manage 54:106-115.

Simon, J.L. 1981. The ultimate resource. Princeton University Press, Princeton, N.J.

United Nations. 1994. World population growth from year 0 to stabilization. Population Division of the Department of Social Reformation. Document, 6/17/94. United Nations Secretariat, New York, N.Y.

United Nations. 1998. World population projections to 2150. Population Division of the Department of Economic and Social Affairs. United Nations Secretariat, New York, N.Y.

United Nations Development Programme. 2000. World resources 2000-2001. Elsevier Science, New York, N.Y.

United States Department of Agriculture Natural Resources Conservation Service. 1992. National resources inventory. Government Printing Press, Washington, D.C.

Wackernakel, M. and W. Rees. 1996. Our ecological footprint. New Society Publishers, Gabriola Island, British Columbia, Canada.

Ward, N. 1999. Ranchers need support for sustainable ranching: What government can do. A ranchers perspective. Rangelands 21 (3): 13-17.

West, N.B. (Ed.). 1995. Biodiversity on rangelands. College of Natural Resources, Utah State University, Logan, U.T.

Photo ID for page 38.

This small family cattle ranch in Oregon pro vides a wide variety of ecosystem services such as wildlife, clean water, clean air and open space to the local community. Its existence is now threatened by low profit margins and encroaching development. 